\title{
Grave Matters: Juan Eusebio Nieremberg's Partida a la eternidad (1643) and Jesuit Approaches to Death in Early Modern Spain
}

\author{
D. Scott Hendrickson, S.J. \\ Department of Modern Languages and Literatures, Loyola University \\ Chicago, Chicago, IL, USA \\ dhendrickson@luc.edu
}

\begin{abstract}
This article examines the key themes in Juan Eusebio Nieremberg's Partida a la eternidad and its relationship to the Jesuit production of ars moriendi tracts in early modern Spain. Special attention is given to the intended readership of this and other similar texts, the focus Nieremberg places on the reading of devotional books and treatises, and the manner in which Jesuit death manuals came to reflect the emerging apostolic goals and the spiritual tradition in the Society of Jesus around the time of its first centenary. Here, the author highlights Nieremberg's inclusion of imaginative and visual contemplations, his approach to condemnation and hell, and the rhetoric he develops around the joy and delight readers are invited to experience in the actual, or imagined, states of illness and dying.
\end{abstract}

\section{Keywords}

ars moriendi - Juan Eusebio Nieremberg - devotional literature - Spanish asceticism - Partida a la eternidad - Ignatius Loyola - Spiritual Exercises - vanitas imagery

Tolle, lege: take up and read -ST. AUGUSTINE, CONFESSIONS 
In the sixteenth and seventeenth centuries, Jesuits considered the writing of books much in the same way they understood being part of an institutional apostolic work, not unlike administering sacraments in a parish, teaching in a school, or directing retreatants in the Spiritual Exercises (1548) of St. Ignatius of Loyola (c.1491-1556). Writing was deemed part of the greater "ministry of the Word," which included preaching, spiritual conversation, and catechesis in cities and rural missions, both in the pulpit and out, in plazas, prisons, inns, and hospitals. ${ }^{1}$ Of the many types of books they wrote, they stand out for their production of manuals on the art of dying: some twenty were published between 1575 and 1620, which rose to 139 between 1621 and 1700 , and at least 101 were printed between 1701 and 1800. ${ }^{2}$ Many of these were written in Spain, where in the seventeenth century Jesuit texts came to outnumber those produced by Franciscans in the previous century. ${ }^{3}$ Among the Jesuit authors, Juan Eusebio Nieremberg (15951658) stands out for the dissemination of his Partida a la eternidad, y preparación para la muerte, published in 1643 , in which he prescribes the spiritual exercise of reading as a way to "entertain" oneself, as it were, with one foot already in the grave. This paper seeks to examine the role Nieremberg ascribes to devotional and ars moriendi literature in the Partida, the significance it has for him as a writer in the Society of Jesus, and why it came to be widely disseminated in early modern Spain and colonial Latin America, and in doing so it seeks to explore not only the Jesuit and Ignatian character of the manual, but how and why developing a corpus of literature on the theme of dying emerged with such prominence for Nieremberg and his companions in the order.

\section{Juan Eusebio Nieremberg}

Born of German parents in Madrid, Nieremberg received his education in the Colegio Imperial of the Jesuits. He then went to Salamanca as a university

1 For more on the Jesuit "ministry of the Word," see John W. O'Malley, The First Jesuits (Cambridge, MA: Harvard University Press, 1993), 91-115; O'Malley, "Early Jesuit Spirituality: Spain and Italy," in Saints or Devils Incarnate (Leiden: Brill, 2013), 121-45, here 129; and Félix Herrero Salgado, "El ministerio de la palabra en las Constituciones de la Compañía de Jesús," in La oratoria sagrada española de los siglos XVI y XVII, 5 vols. (Madrid: Fundación Universitaria Española, 1996-2006), 3:50-93. An earlier draft of this article was presented at the annual conference of the Renaissance Society of America in Chicago on March 31, 2017.

2 Carlos Eire, From Madrid to Purgatory: The Art and Craft of Dying in Sixteenth-Century Spain (New York: Cambridge University Press, 1995), 28.

3 Fernando Martínez Gil, Muerte y sociedad en la España de los Austrias (Cuenca: Universidad de Castilla-La Mancha, 2000), 54. 
student, but only briefly. Finding himself once again under the tutelage of Jesuits, the young Juan Eusebio made a retreat following Loyola's Spiritual Exercises and entered the Society of Jesus in 1614, which eventually led to his becoming a fully professed member of the order. Nieremberg would spend the rest of his life both in the Society and in the same Colegio in Madrid, where he taught classes in Scripture and natural philosophy, served as royal confessor, and where, writing some seventy-five books in Spanish and Latin, he also came to be known in his own right as a literary giant of spiritual and devotional literature. Nieremberg is most remembered for De la diferencia entre lo temporaly eterno (1640), which was printed in numerous editions and translated throughout Europe and abroad. ${ }^{4}$ Both this treatise and his widely disseminated catechism, Práctica del catecismo romano (1640), were used for public readings and the delivery of homilies, so much so that people commonly referred to one or the other more simply as the "Eusebio." Although he seems to have been more of an ascetical recluse, by these two books and his voluminous literary production Nieremberg came to be a household name of sorts in Spain during the seventeenth and eighteenth centuries. ${ }^{5}$ While Nieremberg gives attention to many themes in his works, he is especially prolific concerning human mortality and the afterlife.

\section{Jesuits and the Ars moriendi}

It was not uncommon for Spaniards to hear or read about death in the seventeenth century. The century had in fact begun with the great plague of 1599-1600, with disease, famine, and war beleaguering the country for many decades. ${ }^{6}$ Facing these circumstances, and the stark reality of eternal damnation and the common belief in the existence of hell, Spaniards considered the

4 Regarding the dissemination of the treatise, see Ignacio Iparraguirre, "Un escritor ascético olvidado: El Padre Juan Eusebio Nieremberg (1595-1658)," Estudios eclesiásticos 32 (1958): 427-48, here 427. For more on Nieremberg's vast literary production, see Carlos Sommervogel, Bibliothèque de la Compagnie de Jésus $[B C J], 12$ vols. (Heverlee-Louvain: Éditions de la Bibliothèque S.J., 1960), 5:1725-66.

5 A complete autobiographical account on Nieremberg can be found in Hugues Didier, Vida y pensamiento de Juan E. Nieremberg, trans. M. Navarro Carnicer (Madrid: Universidad Pontificia de Salamanca, 1976), 45-54. Regarding Nieremberg and his Jesuit life, and for more on the two "Eusebios," see D. Scott Hendrickson, Jesuit Polymath of Madrid: The Literary Enterprise of Juan Eusebio Nieremberg (1595-1658) (Leiden: Brill, 2015), 17-20, 51-52, 131.

6 John H. Elliott, Imperial Spain, 1469-1716 (London: Penguin, 2002), 298, 353. 
end of life with utmost importance. ${ }^{7}$ Cervantes, for one, ends his novel Don Quixote (1615) with the old knight uttering in his deathbed: "Señores, I feel that I am dying very rapidly; let us put all jokes aside and bring me a confessor to hear my confession [...], for at critical moments like these a man cannot play games with his soul." ${ }^{8}$ On the stage, even one so notorious as Tirso de Molina's character Don Juan Tenorio in the Trickster of Seville (1617), famous for having lived a life of debauchery and hastily brushing aside the prospect of divine judgment, calls out for confession in the final moments of his life: "Let me call for one to whom I may confess and receive absolution [...] for I am on the threshold of death." ${ }^{9}$ While these references come from well-known works of fiction, they serve to underscore how early modern Spaniards dared not take for granted their fate in the afterlife. Not surprisingly, human mortality was a common theme in sermons and devotional books of wide circulation, such as in the famous preacher and catechist Juan de Ávila's (1499-1569) Audi filia (1556), where he states: "Consider all this, through which you must pass, and think of what kind of thing your body will be under the ground, and how soon it will come to pass, that whosoever loves you the most will not endure to see you, smell you, or even get close to you."10 By the middle of the century, Nieremberg's Partida came to join a long list of similar works. The German printer Pablo Hurus (d.1505) was the first in Spain to produce a text on the art of dying, in Zaragoza in $1480 .{ }^{11}$ Two publications, the De praeparatione ad mortem by Erasmus of Rotterdam (1466-1536) in 1534 and the Agonía del tránsito de la muerte by Alejo Venegas (1498-1562) in 1537, helped to popularize the ars moriendi in Spain, and the printing of related works increased steadily through the seventeenth century. ${ }^{12}$ As Jesuits eventually came to corner the market on this type of manual, they also contributed on a large scale to the so-called

7 For more on the idea of hell in early modern Spain, see Carlos Eire, "The Good Side of Hell: Infernal Meditations in Early Modern Spain," in Historical Reflections 26 (2000): 285-310.

8 Miguel de Cervantes, Don Quixote [1605, 1615], trans. Edith Grossman (New York: HarperCollins, 2003), 936.

$9 \quad$ Tirso de Molina (attributed to), El burlador de Sevilla [1617], ed. Alfredo Rodríguez LópezVázquez (Madrid: Cátedra, 2013), 255. Unless otherwise noted, all translations are mine. Juan de Ávila, Audi filia...Translated out of Spanish into English [1556] (1620), ed. D. M. Rogers (Menston, Yorkshire England: Scolar Press, 1970), 30o. The modernized English is my own.

11 Martínez Gil, Muerte y sociedad, 63-64. For more on the Jesuits and ars moriendi, see Martínez Gil, Muerte y sociedad, 72-74; Eire, From Madrid, 28; and Pedro Rueda Ramírez, "Las artes de buena muerte en el comercio de libros con América: Aproximación a la circulación de la literatura devota en el Siglo de Oro," in Discurso religioso y Contrarreforma, ed. Eliseo Serrano et al. (Zaragoza: Instituto Fernando el Católico, 2005), 141-59, here 151. 
sub-genre of ascetical treatises centered on the theme of the postrimerias, the four last things: death, judgment, heaven, and hell. ${ }^{13}$ Given the editorial success of De la diferencia entre lo temporal y eterno, here again Nieremberg stands out as one of the leading writers in this category.

In De la diferencia, Nieremberg urges readers to consider the significance of life beyond the grave. In light of the four last things, he grabs the attention of his audience by depicting the perishable nature of the material world as Juan de Ávila had done, but also includes lengthy descriptions of the human body in various stages of putrefaction:

Consider what it would be like to be dead for eight days; what would become of you, and how horrendous a sight you would be if your grave were opened? How would you be different from a dead dog, worm-eaten and left in the middle of a pigsty? Look, then, how you regale yourself, your body, which in the span of four days could be full of disgusting worms. ${ }^{14}$

The historian Pedro Rueda Ramírez understands this heightened use of vanitas imagery in the seventeenth century as part of a "pedagogy of fright" meant to dissuade readers from the dangers of worldly, or temporal, delights. ${ }^{15}$ However, Carlos Eire stresses how early modern Spaniards held the attitude that death and all its effects was a normal part of life, not "something unto itself, or something 'other,' but a point on a continuum." ${ }^{16}$ The title of Nieremberg's Partida reflects just this, that death was viewed as an extension of life in terms of a journey from this world to the next. ${ }^{17}$ How one would spend the eternal afterlife therefore required careful preparation.

The corpus of religious works produced in early modern Spain was in itself significant. In addition to the death manuals, devotional treatises, spiritual guides, and hagiographies were published in great numbers. According to Keith Whinnom, the literary merit of devotional literature did not necessarily

13 On the literary production of ars moriendi, see Martínez Gil, Muerte y sociedad, 53-54; on the postrimería-themed treatises, see Fernando Martínez Gil, "Acuérdate de tus postrimerías y no pecarás jamás: Las implicaciones del modelo de la buena muerte," Historia social $5^{8}$ (2007): 23-46, here $26-31$.

14 Juan Eusebio Nieremberg, De la diferencia entre lo temporal y eterno: Crisol de desengaños con la memoria de la eternidad, postrimerías humanas y principales misterios divinos (Madrid: María de Quiñones, 1640), 91.

15 Rueda Ramírez, "Las artes," 151.

16 Eire, From Madrid, 525.

17 Sebastián de Covarrubias defines the verb "partir" as moving from one place to another ("mudarse de un lugar a otro," Tesoro de la lengua castellana o española [1611], ed. Martín de Riquer (Barcelona: Editorial Alta Fulla, 2003), 854; s.v. Partir. 
match the sophistication of structure and style found in some of the more popular secular works published contemporaneously, but the volume in which they were printed and their presence on bookshelves all throughout Spain is worth noting when taking into account the works that have now come to be deemed as "best-sellers." ${ }^{18}$ One example is Fray Luis de Granada's (1504-88) Libro de oración (1554), which had an editorial success even greater than its more secular rivals, such as Fernando de Rojas's (1465/73-1541) La Celestina (1499). ${ }^{19}$ Alison Weber also suggests that early modern readers were drawn to read devotional books for many reasons beyond their more obvious religious appeal and the attention they give to the spiritual anxieties of the time: "It is probable that many readers derived delight as well as edification from these books, whether in narrative invention, rhetorical fireworks, innovative comparisons, rhythmic phrasing, or colloquial style."20

The Jesuit contribution to devotional literature and, more specially, the growing production of ars moriendi in the seventeenth century includes works by Juan Alfonso de Polanco (1517-76), whose Methodus ad eos adiuvandos, qui moriuntur (1575) was translated and published in Spanish as Reglay orden para ayudar a bien morir a los que se parten de esta vida in 1578; Francisco Escrivá (1530-1617), who published the Discurso sobre los cuatro novísimos in 1604; Robert Bellarmine (1542-1621), whose Ars bene moriendi (1620) was translated into Spanish in 1624; Luis de la Puente (1554-1624), who wrote-among other similar treatises- the Práctica de ayudar a bien morir in 1636; Martín de Roa (1561-1637), whose Estado de las almas de purgatorio was published in 1619; Juan Bautista Poza (1588-1659), with his Práctica de ayudar a morir (1619); Alonso de Andrade (1590-1672), who published his Arte de bien morir in 1650; and Manuel de Ortigas (1609-78), whose Guía del cristiano para el cielo was printed in $1659 .{ }^{21}$ The influence of Polanco's seminal work was duly noted almost a century later in a manual called Notte malinconiche, published in 1658 by Giacinto Manara (1598-1662), who praises the "buona dottrina" (good teachings) in Methodus ad eos adiuvandos, qui moriuntur. ${ }^{22}$ Once again,

18 Keith Whinnom, "The Problem of the 'Best-Seller' in Spanish Golden-Age Literature," Bulletin of Hispanic Studies 57 (1980): 189-98, here 196-97.

19 Whinnom, "The Problem," 194.

20 Alison P. Weber, "Religious Literature in Early Modern Spain," in The Cambridge History of Spanish Literature, ed. David Thatcher Gies (Cambridge: Cambridge University Press, 2004), 149-58, here 158 .

$21 \quad$ See $B C J, 1: 322 ; 1: 1244-45 ; 3: 445 ; 5: 1958 ; 6: 944 ; 6: 1135 ; 6: 1891 ; 6: 1285-86$. For more on these and other Jesuit authors, see also Martínez Gil, Muerte y sociedad, $55^{-56}$.

22 Giacinto Manara, Notte malinconiche, nelle quali con occasione di assistere a condannati a morte si propongono varie difficolta spettanti a simile materia [1654] (Bologna: Giovanni Battista Ferroni, 1658), 5. See also BCJ, 5:455-56. 
however, Nieremberg holds a significant place in the history of this body of literature. His Partida was among the most printed texts on the art of dying in Spain, and soon after its publication it was one of the books of this kind to be exported to Spanish America in the highest quantity. Such editorial success on both sides of the Atlantic can perhaps be explained by its use Jesuit colleges in Spain and elsewhere, as Rueda Ramírez suggests. ${ }^{23}$ However, its wide dissemination can also be understood by considering two characteristics of the manual: the readership Nieremberg had in mind for it and the rhetoric he develops in it around the reading of books. Seen together, however, these aspects also allow us to identify a third characteristic of the manual in how it reflects Jesuit thought and spirituality. In my analysis, I aim to show how, in his death manual, Nieremberg came to reflect the apostolic principles and spiritual tradition of his religious order at the time of its first centenary.

\section{Tolle, Lege}

First, the readership. Many of the ars moriendi tracts were written for priests and confessors who accompanied the sick and dying at their deathbeds. Some twenty years earlier, Poza had noted the lack of proper training in this area, and therefore wrote his Práctica de ayudar a bien morir precisely for the purpose of aiding those who assisted people in the process of dying: "It seems necessary to teach those who might have the capacity to undertake this ministry by training them in how to help people die a good death. They and anyone else who knows how to read will have the capacity to do so by taking advantage of what this book has to offer."24 Poza attempts to reach a greater number of readers who would be able to help the dying, yet his audience is still limited to those self-selective readers capable of providing such a service. Nieremberg, on the other hand, widens the scope of his readership by addressing not only the curas de almas, but all Christians who wish to avoid a "bad death," one leading to eternal punishment in hell. At the outset, he addresses an apparently moribund reader who is already on the deathbed by stating in the opening lines: "For this reason I place before you a brief summary of what the ill must do in facing their ailments." ${ }^{25}$ His greater intention, though, is to address all

23 Rueda Ramírez, "Las artes," 150, 152. See also BCJ, 5:1750-51; Martínez Gil, Muerte y sociedad, 55-56; and Antonio Palau y Dulcet, Manual del librero hispanoamericano, 2nd ed., 28 vols. (Barecelona: Libería Palau, 1923-77), 11:55.

24 Juan Bautista Poza, Práctica de ayudar a bien morir [1619] (Madrid: Carlos Sánchez, 1644), 1. See also $B C J, 6: 1135^{-3} 6$.

25 Juan Eusebio Nieremberg, Partida a la eternidad, y preparación para la muerte (Zaragoza: Pedro Verges, 1643), 2. 
sorts of people in good health as well as the dying, and their confessors, which is a point he makes clear in chapter one:

It is not my intention to instruct confessors in how they ought to treat those who are ill, putting them on the path to greater health, consoling and helping them in dying a good death, all of which is thoroughly explained in many books, but to advise those who are in good health in what they ought to do when they fall ill, as well as those who are already ill, to teach them how they ought to predispose themselves, in as much as they can, to prepare for a happy death-which it will be if they are saved. ${ }^{26}$

In his endorsement of the Partida, Fray Martín Jiménez indicates Nieremberg's attempt in this regard, praising him for his "persuasive eloquence" and his ability to speak to a much broader readership, including the young: "This book is very important for all, children, men and the aged."27

One of the ways in which Nieremberg attempts to capture the attention of his readers is by appealing to their imagination. Even more, he encourages the intense, or vigorous, use of it, suggesting in the dedication that readers ought to contemplate the significance of death "con vehemente imaginación." ${ }^{28}$ Here Nieremberg urges readers to meditate over each day of the week, which leads to imagining one's own death and burial:

On Monday ponder with vigorous imagination that you find yourself fallen ill. On Tuesday ponder being cold and that you have a high fever-for not infrequently people enter into a feverish state by vigorous use of the imagination. On Wednesday you must make a diligent confession, as if you were about to die. On Thursday you should ponder receiving Communion as if it came to you by the hand of the Lord together with his Apostles in the Last Supper. On Friday, prepare in thought that you are to receive the holy unction of Last Rites, which will happen by anointing and blessing you with the blood of the crucified Christ. On Saturday ponder that you are already dead, that you have been buried, that your grave has been trampled, and that you have been forgotten. On Sunday you will be resurrected with the Lord and enter into your celestial home. ${ }^{29}$

26 Nieremberg, Partida, 2.

27 Nieremberg, Partida, fol. $96^{\mathrm{v}}$.

28 Nieremberg, Partida, fol. $\Upsilon_{3} 3^{\mathrm{r}}$.

29 Nieremberg, Partida, fols. $\llbracket 3^{\mathrm{r}}-\llbracket 3^{\mathrm{v}}$. 
According to Nieremberg, the power of the imagination is great enough even to induce the physiological reality, the "feverish state," one wishes to experience. All readers, whether they are ill or not, must remember that they are mortals, that it is impossible to avoid death, and that even those with robust health ought to accept this prudent advice and vividly imagine themselves in the same predicament as those who are suffering a grave illness. ${ }^{30}$ The "sick" reader, whether the illness is actual or imagined, is then instructed to ponder the reality of death and to prepare for its imminent arrival.

The shift in readership and the attempt to reach a broader audience reflects how death manuals had begun to change in scope and focus. According to Eire, "The art of dying should not only open the gates of heaven at the moment of death but also show one how to live a good Christian life. The ars moriendi, then, was transformed into an art of living, or ars viviendi."31 Such a shift in appealing to wider audiences can also be said to have been a particular concern for Nieremberg, who applied the same approach to other works he published in Spanish. For example, he claims to have written his miscellanies of natural philosophy (Curiosa filosofía, 1630; and Oculta filosofía, 1633) because so many people unable to read in Latin had convinced him to share his knowledge more widely by writing in the vernacular. ${ }^{32}$ Likewise, he prepared his catechism, Práctica del catecismo romano, a more popular version of the Roman catechism that had been promulgated in the Council of Trent (1545-63) for the use of ordained preachers, by putting it into Spanish and by adding tales and anecdotes to illustrate its doctrinal teachings in a more palatable manner for all Christians, both the clergy and the laity. ${ }^{33}$

Nieremberg also made his death manual more accessible by enhancing its practical function and adaptability. It was originally published in twenty-one brief chapters, and includes an extensive appendix containing prayers, spiritual exercises, and other readings in both Spanish and Latin, such as the litanies composed in honor of Christ and the Blessed Virgin. The spiritual exercises include the profession of faith, prayers of various saints, from Augustine (354430 ) to the Jesuit Francisco de Borja (1510-72), and exclamations of devotion, the "affectionate sighs, taken from Saint Gertrude." ${ }^{34}$ While Nieremberg does not say anything more about St. Gertrude, the mention of her name is worth noting. The thirteenth-century Gertrude the Great of Helfta (1256-1302) was

30 Nieremberg, Partida, 11.

31 Eire, From Madrid, 25.

32 Hendrickson, Jesuit Polymath, 93.

33 Hendrickson, Jesuit Polymath, 64-65.

34 Nieremberg, Partida, 100. 
known for her own collection of Spiritual Exercises, published posthumously in 1536, which included suggestions for those preparing for death. These exercises were reportedly read to King Philip II (r.1556-98) in the final hours of his life. ${ }^{35}$ This nod to the saint and the implied use of her book by the venerated king could perhaps be interpreted as the author's subtle attempt to signal the importance of reading devotional literature and the ars moriendi, which will be explained in greater detail below. ${ }^{36}$

The appended selection of additional material comprises most of the book and underscores the functional aspect of the manual. Readers could use it according to their needs or particular devotional practices. Stressing the importance of the reader's own participation and conviction, Nieremberg expanded the second edition by inserting a "Testamento," or will, which was meant to be signed by the reader, or listener, as a type of spiritual exercise in and of itself, and includes instruction for it to be marked with the figure of the cross should the person be unable or not know how to write. ${ }^{37}$ By signing it, people professed their desire to die as faithful members of the church and to make an appropriate confession of their sins, receive the sacramental blessing of last rites, and partake of the holy Eucharist in the event of falling ill. ${ }^{38}$

\section{Prodesse et delectare}

While Nieremberg expands the readership of the Partida by underscoring both the imaginative and practical participation of readers, the second characteristic

35 Gertrude of Helfta, The Herald of Divine Love, ed. and trans. Margaret Winkworth (Mahwah, NJ: Paulist Press, 1993), 43. St. Gertrude's Spiritual Exercises, Book 7, "Life in Death," contains many sighs and affectionate exclamations - that Nieremberg calls "suspiros afectuosos"directed toward God; see Gertrude the Great of Helfta, Spiritual Exercises, ed. and trans. Gertrude Jaron Lewis and Jack Lewis (Kalamazoo: Cistercian Publications, 1989), 122-46.

36 For more on the significance of Philip II's death and its mention in ars moriendi, see Eire's chapter, "Drawing Lessons from the King's Death," in From Madrid, 300-21.

37 Nieremberg, Partida, 126-31 (not all second edition printings contain the "Testamento").

38 One of the copies held in the Biblioteca Nacional de España in Madrid bears three identical signatures on the frontispiece, which may have served as the "Testamento" to its owner. See also "Testamento, y última voluntad del alma," in Nieremberg, Partida, 126-31. For more on the "Testamento," see Rueda Ramírez, "Las artes," 155; and Ildefonso Adeva Martín, "Ars bene moriendi: La muerte amiga," in Ante la muerte: Actitudes, espacios y formas en la España medieval, ed. Jaume Aurell and Julia Pavón (Pamplona: Ediciones Universidad de Navarra, 2002), 295-360, here $33^{6-38}$. For more on the "Testamento" as a spiritual exercise, see Eire, From Madrid, 23. Fernando Martínez Gil explains how testamentos are used for data collection, in "Del modelo medieval a la Contrarreforma: La clericalización de la muerte," in Ante la muerte, 217-18, and "Actitudes ante la muerte e historia social en la España moderna," Historia social 16 (1993): 19-32, here 20. 
of the manual worth exploring is the rhetoric he develops in it around reading. According to him, the preparation of a good death ought to include the habitual spiritual exercise of reading all types of devotional literature. In a chapter containing various suggestions for one who is sick, he states: "From time to time urge those assisting you to read to you from the litanies of the saints, the [litanies] of Our Lady, and some book of devotion, or from Sacred Scripture."39 In a later chapter he reiterates this instruction, but also provides a detailed list of books for this purpose. He begins with Sacred Scripture, giving priority to the Book of Job, Song of Songs, Acts of the Apostles, and the gospels. The next section contains two selections from the Divine Office, followed by a list of devotional books that includes works attributed to St. Augustine, various works of St. Bernard (1090-1153), the Meditaciones del alma a su Dios (1588) of Teresa de Ávila (1515-82), the Lives of the Saints (1578) of Alonso de Villegas (1533-1603), the collected works of Fray Luis de Granada (1504-88), the letters of Juan de Ávila, several spiritual treatises prepared by other Jesuits, and, in what almost seems to be an element of self promotion, six of his own works, including De la diferencia entre lo temporal y eterno. ${ }^{40}$

For Nieremberg, these books are beneficial because they teach readers how to grow in sorrow for the sins they have committed during a lifetime, and they urge readers to express gratitude for the graces God bestows. Ultimately, they instruct people how to conform the will to that of God, even in the manner of dying they must suffer. As noted above, not even Philip II exempted himself from being read to in the final days of his life. ${ }^{41}$ The reading of devotional literature could have the effect of leading an individual to greater introspection, which is what Juan de Ávila noted in the Audi filia in his instructions toward gaining better self-knowledge: "Take first some book of good instruction, wherein, as in a mirror, you may see your faults, so that your soul may then be nourished as it is encouraged in the ways of God."42 Nieremberg deems the passing of time in this way a "holy exercise," and goes on to cite the example of St. Ignatius, who in his own illness, prayer, and convalescence as a knight read

39 Nieremberg, Partida, 68.

40 Nieremberg, Partida, 73-78. Other works mentioned by Nieremberg are the printed homilies of Fray Jerónimo Bautista de Lanuza (1553-1624), two spiritual treatises of Ludovico Blosio (1506-66), the Tratado de la oración of Antonio de Molina (156o-1619), the Arte de amar a Dios (1625) of Fray Juan de Jesús María, selections from the Meditaciones (1605) of Luis de la Puente, the Tratado de perfección (1609) of Alonso Rodríguez, and more of his own spiritual treatises, including Llamas del amor divino (c.1641), the Saetas (1640), De la afición a Jesús (1630), De adoratione in espritu (1631), and parts of his Theopoliticus (1641).

41 See Eire's section, "Philip's Devotional Reading," in From Madrid, 325-28.

42 Ávila, Audifilia, 296. 
the Life of Christ (1374) of Ludolph of Saxony (c.1295-1378) and the Lives of the Saints, or the Golden Legend (c.126o), of Jacobus de Voragine (d.1298). ${ }^{43}$ These texts contributed to his own spiritual conversion and gave him the conviction to go on and perform saintly deeds not in honor of his family or his name, but of God. Nieremberg explains: "I therefore specifically urge the undertaking of this holy exercise and wish to recommend from among the most noteworthy of books those which will help the sick." ${ }^{44}$

The combination of contemplative, or mental, prayer and devotional reading exemplified in the conversion of Loyola also reflects a wider trend in devotional practices during the early modern period in Spain..$^{45}$ The more successful writers, Weber explains, found a way formulate the didactic message of their texts by creating a sense of "delight as well as edification" for readers. Here Fray Luis de Granada once again stands out:

He appeals to his reader frequently in the singular familiar and varies his instructions with parables, proverbs, and homey comparisons, almost always in a tone that is intimate and consoling rather than reproachful. Although his style, replete with rhetorical questions, exhortations, and exclamations, may strike modern readers as sentimental, his phenomenal publishing record attests to his success in touching the well-springs of early modern sensibilities. ${ }^{46}$

In the introduction to his Práctica del catecismo romano, published just three years before the Partida, Nieremberg praised Granada for creating the Compendio de doctrina cristiana (1559) and sought to imitate its style by producing a catechism that could likewise be used for preaching, thereby making the doctrinal teachings more accessible. For this, Nieremberg included tales and anecdotes as "entertaining digressions" intended to make the catechetical

43 Nieremberg, Partida, 74. For more on the editions St. Ignatius read, see Joseph de Guibert, The Jesuits: Their Spiritual Doctrine and Practice, trans. William J. Young and ed. George E. Ganss (St. Louis, MO: Institute of Jesuit Sources, 1972), 152-57; the editors' notes in Obras de San Ignacio de Loyola, ed. Ignacio Iparraguirre et al., 6th ed. (Madrid: Biblioteca de Autores Cristianos, 1997), 102; Javier Melloni, "Los Ejercicios espirituales, un eslabón en la tradición de occidente," EIDES (Escola ignasiana d'espiritualitat) 23 (1998): 5-47, here 7-9; and Terence O'Reilly, "Early Printed Books in Spain and the Exercicios of Ignatius Loyola," Bulletin of Spanish Studies 89 (2012): 635-64, here 653-54.

44 Nieremberg, Partida, 74.

45 Weber, "Religious Literature," 152.

46 Weber, Religious Literature," $153-54$. 
lessons more relatable to his listening audience. ${ }^{47}$ Similarly, reading or listening to books is meant by Nieremberg to be a source of spiritual consolation and even entertainment, which he indicates toward the end of the final chapter: "Whereby those who are ill will be able to choose and have something with which to console and entertain themselves in their suffering."48 Accordingly, the experience of suffering and even dying ought to be considered an opportune moment not of terror, but of joy, since dying a good death placed the sick person on the threshold of one's true destiny, union with God in the afterlife. Illness is given to people for a spiritual reason because it brings about the opportunity to recognize the vulnerable condition of human life and its temporal limitations, forcing the stricken to concentrate on life everlasting. In chapter two of the Partida, Nieremberg advises: "Do not think in terms of natural causes, which is where illnesses can and tend to come from, but in God, who through these trials either desires to give me a crown of glory, or through them seeks to punish me for my faults by giving me this living purgatory." 49 Equating sickness to an earthly experience of trial, he reiterates: "God gives me this illness [...] [and] wants to cure something in me, for he has taken my pulse, and according to my need he has applied the medicine." ${ }^{\circ 0}$ Rather than see illness an ailment of the body, here it is deemed a medicine of the soul and a crown of glory. It is a favorable experience because it gives an individual the chance to put the spiritual life in order: "Persuade yourself how important it is to fall ill with such delight. Perhaps instead you would have had a great misfortune, had you not now fallen into your sickbed." ${ }^{1}$

Nieremberg was not the only writer of ars moriendi who aimed to console the dying by entertaining them in their trials. According to Ildefonso Adeva Martín, writers in the sixteenth century developed themes around the reception of death as a friend, or even a lover. ${ }^{52}$ In Arbol de consideración (1584), Pedro Sánchez equates death to a meal, which is meant to be prepared, sweetened, and served to the dying as a palatable dish. ${ }^{53}$ In his widely published and translated treatise for Jesuits on how to live religious life well, Ejercicio de

47 Hendrickson, Jesuit Polymath, 59-6o.

48 Nieremberg, Partida, 77-78.

49 Nieremberg, Partida, 9.

50 Nieremberg, Partida, 10.

$51 \quad$ Nieremberg, Partida, 6.

52 Adeva Martín, "Ars bene moriendi," 309-10. For more on consolation in Nieremberg's manual and those of other authors, see Martín Eduardo Vargas Poo and Silvia Cogollos Amaya, "La teología de la muerte: Una visión española del fenómeno durante los siglos XVI al XVII," in Inquisición, muerte y sexualidad en el nuevo reino de Granada (Bogotá: Ariel, 1996), 117-42, here 125 .

Rueda Ramírez, "Las artes," 146. 
perfección y virtudes cristianas (16o9), Alonso Rodríguez (1538-1616) invites his companions in the order to wait for the hour of death with the same anticipation of a bride on her wedding day. ${ }^{54}$ And in his treatise Consuelo de enfermos, y atribulados (1668), originally published in De la perfección del cristiano en todos sus estados in 1612, de la Puente wrote that the benefits of being sick included physical pain and discomfort, and ought to be considered gifts from God: "Illnesses tame the unbridled horses that are our bodies by squelching the flames of our passions and preventing them from overtaking the [weakened] soul, unable to subdue them."55 Nieremberg uses the same image of the horse in the Partida because it represents the lack of reason and the inability to ponder life in the hereafter: "Do not let yourself die like a horse, ignorant of all things eternal. Rather, appreciate what is at stake, and see how precious your soul is." 56 The suffering of the body may be seen as a punishment the afflicted must endure, but Nieremberg's "persuasive eloquence" can be noted in persistent references to the joy, delight, and consolation given to the sick: "In your surrender you will find immense joy and the most extraordinary peace [...]. And given that the [stricken one] not seek, desire, or receive joy in anything other than God, so he or she will find in all that is bitter and adversary the greatest sweetness." 57

The Partida therefore serves a dual purpose to teach readers how to approach the end of life as well as comfort and entertain them in their suffering. In the seventeenth century, Spanish theorists adopted the Horatian maxim that literature should both teach and please (prodesse et delectare). ${ }^{58}$ While the

54 Alonso Rodríguez, Ejercicio de perfección y virtudes cristianas [16o9] (Barcelona: Autores Católicos Escogidos, 2010), 611. For more on the dissemination of this work, see John Patrick Donnelly, "Alonso Rodríguez's Ejercicio: A Neglected Classic," Sixteenth Century Journal 11 (1980): 16-24.

55 Luis de la Puente, Consuelo de enfermos, y atribulados [1612] (Pamplona: Martin Gregorio de Zabala y Labayen, 1668), 13. La Puente wrote De la perfección del cristiano en todos sus estados in 1612, which included advice for the sick and moribund and was later published separately as a death manual. The Tesoro escondido en las enfermedades, y trabajos... con una práctica de bien morir (date unknown) is also attributed to de la Puente. For more on de la Puente's works of ars moriendi, see Adeva Martín, "Ars bene moriendi," 355; Martínez Gil, Muerte y sociedad, 73; and $B C J, 6: 1271,1285$, 1293. Meditations on the "postrimerías" can also be found in chapters seven and eight of de la Puente's Meditaciones espirituales; see also Rueda Ramírez, "Las artes," 151.

56 Nieremberg, Partida, 4.

57 Nieremberg, Partida, 9.

58 See Jeremy Robbins, The Challenges of Uncertainty: An Introduction to Seventeenth-Century Spanish Literature (London: Duckworth, 1998), 15; and Stephen Boyd's introduction in A Companion to Cervantes's Novelas ejemplares, ed. Stephen Boyd (Woodbridge, UK: Tamesis, 2005), 8-12. 
modern reader may be unaccustomed to such an interpretation of illness, real or imagined, it formed part of the religious mindset of the day. According to Nieremberg, death presents believers with the possibility of seeing God face to face, the ultimate delight of Christians, but they must be adequately prepared for this to happen. Although the manual forces the reader to face a stark reality, it presents a didactic message of consolation, even for the most guilty of sinners. Nieremberg incorporates the literary tastes and conventions of his day, but as a Jesuit writer who contributes to the wider production of devotional literature and the order's wider "ministry of the Word." On the one hand he writes as a doctor of the soul in all its states of sickness and health, while on the other he enhances the literary value of his text by creating a rhetorical strategy around reading literature that both teaches and pleases even those readers who might already have one foot in the grave.

\section{Set Your House in Order}

The third characteristic of Nieremberg's manual worth closer consideration regards the relationship it has to Jesuit thought and spirituality. When the Society of Jesus was founded as a religious order the writing of books was not deemed something Jesuits would undertake as an apostolic work. This was the opinion of Alfonso Salmerón (1515-85), who felt that the ideals of simplicity, modesty, and charity might be better served in other ways. His fear was that Jesuits would become too removed from the official sacramental ministries of the order if they dedicated too much of their time to writing. ${ }^{59}$ However, they soon discovered how books could help them in their work, and before long they began publishing in many disciplines. In one of his works, Nieremberg even uses the image of the book and its component parts, including the printing process, to portray the life of Christ and the acceptance of Christ in one's life in paleographic terms. In a short treatise called Libro de la vida: Jesús crucificado (1634), he explains how the "book" of Jesus was printed in Jerusalem in the printer's office on Calvary, in the year 33. The cost comes with a high price, set in the terms of Christ's sacrifice: the Son of God's blood. Each of the seven chapters focuses on elements of the passion, which are meant to be "imprinted" in the hearts of the faithful. ${ }^{60}$

59 O'Malley, First Jesuits, 114.

6o Juan Eusebio Nieremberg, Libro de la vida. Jesús crucificado [1634], in Vida divina, y camino real para la perfección (Madrid: Imprenta Real, 1635), 187. 
One of the earliest works to be published by the Society of Jesus was Polanco's Methodus ad eos adiuvandos, qui moriuntur in $1575 .{ }^{61}$ Because of its ministerial focus, this and the many manuals that followed came to be seen as beneficial to the Jesuits and their work, especially with the moribund, and, like so many writers in the seventeenth-century Spanish Society, Nieremberg's Partida follows in the tradition established not just by Polanco, but by Loyola. As mentioned above, his own reading of devotional literature led him into greater introspection and helped to bring about his spiritual conversion, and his own writings contain important reflections on death.

In the Constitutions (1558) of the Society that Polanco helped compose, Loyola instructs Jesuits to edify others in all states of health: "As during his whole life, so also and even more at the time of his death, each member of the Society of Jesus ought to strive earnestly that through him God our Lord may be glorified and served and his neighbors edified" (\$595).62 In essence, Jesuits were instructed to prepare themselves for a good death, and in so doing embody the instructions of a death manual and set an example for others. Here we recall Loyola's sole purpose in founding the Jesuit order: "The end of this Society is to devote itself with God's grace not only to the salvation and perfection of the members' own souls, but also with that same grace to labor strenuously in giving aid toward the salvation and perfection of the souls of their neighbors" (\$3). According to O'Malley, no other phrase occurs more frequently in the documents of the early Society than the express desire to help souls, "ayudar a las ánimas," which St. Ignatius is reported to have described as the motive that led him to begin studies in Latin at an advanced age so that he would eventually be able to study theology and engage people in spiritual and religious matters. ${ }^{63}$

With the Spiritual Exercises, Loyola specifically wanted to help people at a deeper level to cultivate their lives by embracing God's will. Such emphasis on cultivating the will was shared among spiritual writers of various traditions, yet Joseph de Guibert recalls how it represents a particular focus of the Jesuits in

61 Eire, From Madrid, 28-29. BCJ, 6:944. According to O'Malley, Polanco's Breve directorium, a confession manual, was among the first works to be published by the Society; see First Jesuits, 114-15; and $B C J, 6: 939$. For more on the earliest Jesuit publications, see also Robert Aleksander Maryks, Saint Cicero and the Jesuits (Hampshire, England: Ashgate / Rome: Institutum Historicum Societatis Iesu, 2008), 32-42.

62 Saint Ignatius Loyola, The Constitutions of the Society of Jesus [1558] (St. Louis, MO: Institute of Jesuit Sources, 1996), 266. All further quotations will come from this edition and will be cited by section number parenthetically in the text.

63 Saint Ignatius Loyola, Autobiography, in Spiritual Exercises and Selected Works, ed. George E. Ganss (New York, Paulist Press: 1991), 65-111, here 91. 
the seventeenth century: "Henceforth, Jesuits were to give strong emphasis to the 'the one thing necessary,' [...] eternal salvation, the fulfilling of God's will, submission to His sovereign dominion and outstanding and perfect service according to the level of the of the souls being addressed." 64 The development of the interior life could also explain, according to Adeva Martín, how Jesuits came to write so many treatises on the art of dying: "All efforts behind the ars moriendi center on stimulating the interior life of the dying toward actively accepting and identifying the divine will." "65 In his endorsement of the Partida Fray Jiménez notes Nieremberg's aim to "help souls" with this and the many other books he wrote: "I worthily condemn all who have sewn their seeds in the winds of vanity, may they gain no harvest. It is not so with Eusebio, who has attempted in all of his writings not to achieve the vain appraisal of his name, but the solid benefit of others." 66

A perspective on death also formed part of Loyola's method of prayer and contemplation. For example, he begins the Exercises with the "Principle and foundation" by asking retreatants to embrace an attitude of indifference, or interior freedom, regarding the state of their health. They should not so much prefer health over sickness or even a longer life over a shorter one, thereby allowing themselves to become spiritually open and more able to accept God's will—no matter how it is made manifest: "To do this, I must make myself indifferent to all created things [...]. Consequently, on my own part I ought not to seek health rather than sickness, wealth rather than poverty, honor rather than dishonor, a long life rather than a short one, and so on in all other matters." ${ }^{27}$ Retreatants are not encouraged to pray for sickness or a shorter life span, but to free themselves of the disordered attachments of the interior life that might block them from receiving the most benefit in completing the Spiritual Exercises. Jesuit writers applied this Ignatian approach to the theme of death in many types of works. In Ejercicio de perfección, Rodríguez refers to St. Gertrude just as Nieremberg would later do in his Partida. According to her hagiographers, Christ once appeared before her with health in one hand and sickness in the other, asking her to choose one over the other. With great spiritual indifference, she responds with the request that God's will, not hers,

\footnotetext{
64 de Guibert, Jesuits, 534 .

65 Ildefonso Adeva Martín, "Cómo se preparaban para la muerte los españoles a finales del siglo Xv," Anuario de historia de la iglesia 1 (1992): 113-38, here 137.

66 Nieremberg, Partida, fol. $\uparrow 4^{\mathrm{r}}$.

67 Loyola, The Spiritual Exercises [1548], in Selected Works, 113-214, here 130 (§23). All further quotations will come from this edition and will be cited by section number parenthetically in the text.
} 
be done. ${ }^{68}$ Rodríguez then goes on to cite the example of St. Ignatius, who relished in the thought that dying would grant him the chance to come face to face with Christ: "In this way, not only will the memory of death not be bitter to us, rather it will give us much happiness and joy" 69

Another example can be found in the contemplations in the first week of the Exercises, where Loyola asks retreatants to engage the senses and imagine souls condemned in the afterlife, suffering for the sins they have committed over a lifetime:

[Here it] will be to see with eyes of the imagination the huge fires and, so to speak, the souls within the bodies full of fire. [...] I will hear the wailing, the shrieking, the cries [...]. By my sense of smell I will perceive the smoke, the sulphur, the filth [...]. By my sense of taste I will experience the bitter flavors of hell [...]. By my sense of touch, I will feel how the flames touch the souls and burn them $(\S \S 66-70)$.

Citing these particular exercises, Eire holds Loyola "among the first to emphasize innovative kinds of meditations on death and the afterlife," and attributes this innovation to the order's success in producing death manuals. ${ }^{70} \mathrm{~A}$ complete set of widely disseminated plate engravings graphically portraying the punishments suffered by the eternally condemned also came to be included in various Jesuit texts, including Nieremberg's De la diferencia. ${ }^{71}$ Loyola's end, and that of the Jesuits who followed suit, like many other spiritual writers in early modern Spain, was not to dwell solely on hell, but to invite people to reform their lives, to transformation, to recognize their identity as creatures loved by their creator, who continually invites them to what Eire calls "the flip side of hell in Baroque piety [...]" that "for many of those who taught about hell, it was no metaphor, but a real place indeed, and they wished to warn others away and, in the process, transform themselves and their societies for the better."72

68 Rodríguez, Ejercicio, 6o3.

69 Rodríguez, Ejercicio, 620.

70 Eire, From Madrid, 28, 518.

71 For more on the series of engravings and their portray of hell in Jesuit texts, see D. Scott Hendrickson, "Early Guaraní Printing: Nieremberg's De la diferencia and the Global Dissemination of Seventeenth-Century Spanish Asceticism," Journal of Jesuit Studies 5, no. 4 (2018): 586-6o9, here 6o8, https://doi.org/10.1163/22141332-00504006; and the more detailed study of Fernando M. Gil, "El ciclo del Añaretá (infierno) en los grabados del De la diferencia entre lo temporal y lo [sic] eterno de Nieremberg, traducido al guaraní e impreso en las reducciones del Paraguay (1705)," IHs: Antiguos jesuitas en Iberoamérica 7 (2019): 4-26.

72 Eire, "Good Side," 309. 
As seen above, Nieremberg invites readers of the Partida to imagine themselves sick, dying, and entering the grave over the course of a week, just as Juan de Ávila had similarly instructed readers of the Audi filia before him. By introducing the Partida in this way, in the form of a week-long retreat and prompting a vigorous use of the imagination, is important to note, because it relates to his own spiritual formation in the Jesuit order. ${ }^{73}$ In the Exercises, Loyola includes instructions regarding the giving of alms and asks retreatants to imagine themselves in the moment of death and on the day of judgment, and to ponder how generous they have been with their wealth and possessions ( $\S 340-41)$. Retreatants are encouraged throughout all of the Exercises to engage the imagination, to contemplate things both visible and invisible, and to apply the meaning of the imagined scenes to their own lives- such as in the meditation on hell. Often these imagined scenes involve places and characters described in the gospels, in an exercise that has come to be known more commonly as the "Composition of place." For example, in his instructions to contemplate the birth of Christ in the second week, he states: "Composition, by imagining the place. Here it will be to see in imagination the road from Nazareth to Bethlehem. Consider its length and breadth [...]. Similarly, look at the place or cave of the Nativity" (§112). The prayer is then enhanced as practitioners of the method are instructed to engage the imagination more vividly by inserting themselves into the particular scene:

This is to see the persons, that is, to see Our Lady, Joseph, the maidservant, and the Infant Jesus after his birth. I will make myself a poor, little, and unworthy slave, gazing at them, contemplating them, and serving them in their needs, just as if I were there, with all possible respect and reverence. Then I will reflect upon myself to draw some profit. (§114)

The "Composition of place" was not original to Loyola, but his use of it in the Exercises has been credited for helping people more widely to become engaged in prayer in a personalized and subjective manner. As Rossano Zas Friz puts it, "with the [composition of place] the exercitants construct the 'scene' in which they will express 'themselves' in the representations of their imagination, which without a doubt will reflect their personal experiences and history."74

73 For more on how week-long retreats in the Spiritual Exercises came into practice in Jesuit circles, see William Bangert, Jerome Nadal, S.J., 1507-1580, ed. Thomas McCoog (Chicago: Loyola University Press), 207-9.

74 Diccionario de espiritualidad ignaciana, ed. José García de Castro et al., 2 vols. (Bilbao: Mensajero/ Santander: Sal Terrae, 2007), 1:361. 
More importantly, it is through the more personalized and affective experience of prayer that a practitioner comes to embrace its meaning: "It is not simply the conjuring of a sensorial point of reference $[\ldots]$ in the contemplation, but the interior reception within the exercitant, which expresses itself in the creation of a subjective and imaginative framework, of the ongoing pedagogic development of the grace. ${ }^{75}$ While Nieremberg does not evoke a biblical scenario in his invitation to employ the imagination, his combination of spiritual exercises, the prayerful approach to reading, and the intense engagement of imaginative contemplation in the format of a personalized retreat echoes the experience and method of his order's founder and the spiritual tradition that developed in the first century of the order's existence.

Other Jesuits incorporated elements of the Ignatian method in their death manuals. Some years later Giovanni Maria Prola $\left(165^{-1732)}\right.$ used a similar approach in Giorno di vera vita consacrato all' apparecchio d'una santa morte (1706), which was translated into Spanish and published in Spain by $1733{ }^{76}$ In it, he urges readers to meditate and ponder "that your Guardian Angel announces to you the very same news to [...] set your house in order, for you shall die."77 This exercise is, however, part of a larger meditative scheme set up in the format of a contemplation similar to those in the Spiritual Exercises. In Loyola's method, it is important for people to predispose themselves in the experience of each prayer: "The preparatory prayer is to ask God Our Lord for grace that all my intentions, actions, and operations may be ordered purely to the service and praise of his Divine Majesty" ( $\$ 46)$. Once this is done, retreatants begin the "Composition of place" assigned to each exercise. Next, they are instructed to ask God for the particular grace they are seeking: "to ask God Our Lord for what I want and desire" (§48). In some contemplations, Ignatius instructs people to perform the "examen of conscience" in order to recognize the disorders of the interior life, which is followed by the sacrament of confession $\left(\S_{2} 2\right)$. Finally, many of the contemplations conclude with the colloquy prayer, as if in conversation with Christ or the Virgin Mary (\$54). Similarly, Prola asks his readers to move beyond the use of the imagination by praying in such a way that they feel for themselves the sting of death: "You must choose one day of every month, with the goal of putting yourself in a state in which you wish to die, exercising yourself in every which way, so as to place yourself

75 Diccionario, 1:361.

76 For more on Prola and his work, see $B C J, 6: 1242-44$.

77 Giovanni Maria Prola, Vía [sic] de verdadera vida, y aparejo para una santa muerte [1706], trans. Don Lesio de Cranquart (Cervera: Imprenta de la Real Universidad, 1739), 8. 
befittingly, not through the imagination, but more in reality, in your deathbed." ${ }^{78}$ Not unlike in the Spiritual Exercises, he instructs his readers to predispose themselves appropriately in a series of meditations provided in his book: "On the night before, you shall read the third paragraph of Need, or the fourth of Profit, or the fifth of Peacefulness." ${ }^{79} \mathrm{He}$ then goes on to explain how readers ought to pray on the particular day they have set aside for these exercises, which includes meditating on death, reading the hymn used in the Mass for the dead, receiving the Eucharist, signing the Testamento, praying in the form of a colloquy, and performing the "examen of conscience." 80 Moreover, all of these exercises are completed in asking for the particular grace to be "in a state in which you wish to die." Also, not unlike Nieremberg, Prola underscores the important place reading has in the process of prayer and meditation: "It is not necessary for one to commit all these points to the intellect; it is enough to read over them slowly and, bit by bit, to ponder the truths they hold." ${ }^{81}$

A final point of connection between the Spiritual Exercises and the Jesuit approach to death worth further comment can also be identified in the focus Nieremberg places on spiritual consolation. As shown above, part of Nieremberg's rhetorical strategy in the Partida includes consoling and entertaining readers by leading them to embrace joy and to recognize divine grace in the experience of agony. This particular emphasis even in the throes of death resonates with the way in which Loyola culminates his method in the most consoling of all his exercises, the "Contemplation for attaining love," known more commonly as the "Contemplatio." Far from the meditations on hell, here retreatants are meant to recall all the grace and benefit they have received from God, and to live in greater acknowledgement of and gratitude for the divine love they have experienced in their lives:

I will call back into my memory the gifts I have received-my creation, redemption, and other gifts particular to myself. I will ponder with deep affection how much God Our Lord has done for me, and how much he has given of what he possesses [...]. Then I will reflect on myself, considering what I on my part ought in all reason and justice to offer and give to his Divine Majesty. (§234)

\footnotetext{
78 Prola, Vía, 3.

79 Prola, Vía, 8.

8 o Prola, Vía, 9-10.

81 Prola, Vía, 5 .
} 
While Nieremberg aims for his readers and listeners to be consoled and at peace in the process of dying, he likewise instructs them to reflect on all they have received from God by including two sets of meditations, "gratitude for divine profits" and "memory of divine profits," both of which closely echo the focus and scope of the "Contemplatio." 82

\section{Conclusion}

The ars moriendi manuals written by Juan Eusebio Nieremberg and others in the Jesuit order received wide dissemination in Spain and colonial Spanish America. Their popularity can be attributed to the importance that was given to the topic of death and the everlasting life in early modern times, especially during decades of plague, famine, and war in seventeenth-century Spain. In the aim to broaden their readership, Jesuit writers enhanced their manuals in ways that would make them more appealing to the imagination and by increasing their functionality. Writers such as Nieremberg also developed a rhetoric around the spiritual exercise of reading on death by focusing on how beneficial, consoling, and even entertaining this exercise could be for people of all ages. These aspects of Nieremberg's Partida a la eternidad and other similar manuals penned by his confrères, however, also speak to their Jesuit, or Ignatian, character, especially as these authors sought to "help souls" in greater numbers. While the manuals may not follow the same schema of the Spiritual Exercises of Loyola, their incorporation of Ignatian ideals and practices is important to note. They lead readers through a similar pedagogical paradigm by offering imaginative and sensorial contemplations on death, including the punishments of hell, but ultimately bring them to embrace the possibility of transforming their lives and the reward of eternal joy. They are an indication of how early modern Jesuits understood the components of what would eventually come to be known as the thought and spirituality of the Society of Jesus. Identifying these ideals and practices in the cultural and religious sensibilities of the time, including the literary conventions contemporary to them, helps us to understand better how and why Nieremberg and other Jesuit writers enhanced the ars moriendi, and why developing a corpus of literature on the theme of death came to be an apostolic priority of the order in the seventeenth century.

82 Nieremberg, Partida, 101-4. 